\title{
Impact of Foreign Investment on Economic Growth in OECD's Members: A Panel Data Model, 1977-2017
}

\author{
Alí Aali-Bujari ${ }^{1}$, Francisco Venegas-Martínez ${ }^{2, *}$ and Tomás Gómez-Rodríguez ${ }^{1}$ \\ ${ }^{1}$ Universidad Autónoma de Estado de Hidalgo, México \\ ${ }^{2}$ Instituto Politécnico Nacional, México
}

\begin{abstract}
Motivation: This paper is aimed at analyzing the impact of foreign investment (FI) on economic growth (EG) in Australia, Canada, Germany, Spain, Finland, France, United Kingdom, Greece, Italy, Japan, Republic of Korea, Mexico, Netherlands, Norway, New Zealand, and USA.

Novelty: The research is: 1) concentrated in countries belonging to the OECD; 2) based on a greater number of countries, variables and periods; and 3) addressed to correcting multicollinearity and autocorrelation of data.

Methodology: A Granger causality analysis is carried out and both static and dynamic panel data models are estimated.

Data and Empirical Analysis: Data is obtained from World Bank for the period 1977-2017. The causality of Granger reveals that during the first 10 years there is a unidirectional relationship from FI toward EG. In the following 15 years, there is empirical evidence of a bidirectional causal relationship. Moreover, during the whole period of study, 7 years have a unidirectional causality from EG toward FI. Finally, estimates of both static and dynamic panel data models show that $\mathrm{FI}$ has a positive impact on EG in all the studied economies.

Policy Considerations: A set of recommendations for policy designers and decision makers is provided to build the appropriate instruments and incentives to encourage the attraction of FI to boost EG and, therefore, to enhance social welfare.
\end{abstract}

Keywords: Economic growth, foreign investment, Granger causality, panel data.

\section{INTRODUCTION}

Foreign investment $(\mathrm{FI})$ has been intensifying with the globalization process in recent decades. The impact of $\mathrm{Fl}$ in recipient countries has been a subject of interest in a long list of theoretical and empirical investigations since Vernon's (1966) and Caves' (1974) pioneer papers; see, for instance: Donges (1976) that carries out a comparative survey in 15 semi-industrial countries; Hartman (1985) that leads with tax policy and FI; Krugman (1991) that studies the relationship between increasing returns and Fl; Fry (1992) that examines the relationship between efficiency and incentives of $\mathrm{Fl}$ in a macroeconomic framework; De Gregorio (1992) that assesses the impact of $\mathrm{FI}$ in economic growth in Latin America; Romer (1993) that finds empirical evidence regarding the effect of $\mathrm{FI}$ on economic development; Hadad and Harrison (1993) that find empirical evidence of positive spillovers from $\mathrm{FI}$ in Morocco by using a panel data model; Greenaway et al. (1995) that carriy out a vertical and horizontal intra-industry analysis for the United Kingdom; Ozawa (1996) that studies the puzzle of managed economic growth and $\mathrm{Fl}$; Borensztein et al. (1998) that show

*Address correspondence to this author at the Instituto Politécnico Nacional, México; E-mail: fvenegas1111@yahoo.com.mx

Clasificación JEL: F21, 010, 016. evidence on the effects of $\mathrm{FI}$ on economic growth; Aitken and Harrison (1999) that find that domestic firms benefit from FI in Venezuela; Mortimore et al. (2000) that deal with corporate strategies for $\mathrm{FI}$ in the context of Latin America's new economic model; Zhang and Felmingham (2001) that study the relationship between $\mathrm{FI}$ and China's provincial export trade; Marquez-Pozos et al. (2003) that examine performance of the $\mathrm{Fl}$ in the Mexican case; Bhagwati (2007) that attempts to explain how multinationals help reduce poverty, Ozturk (2007) that examines the $\mathrm{Fl}$-growth nexus in a cross-national framework, Garriga (2014) that studies the effects of the FI in Mexico; Brahim and Rachdi (2014) that analyze the links among foreign direct investment, institutions and economic growth; and MagnierWatanabe and Lemaire (2018) that examine the behavior of $\mathrm{Fl}$ in Japan. These papers examine the role of $\mathrm{FI}$ in economic activity, and most of them find that $\mathrm{FI}$ has positive effects in the recipient economies regarding their contribution to macroeconomic stability and EG. Among these papers, some suggest that FI contributes to the economic dynamism since $\mathrm{FI}$ facilitate the transfer of technological progress from developed countries to developing countries through multinationals allowing for spillovers. A fine literature review on FI can be found in Al-Qaisi (2017). Finally, most of these authors highlight the existence of a positive relationship between $\mathrm{FI}$ and EG. In this regard, empirical research highlights, from different 
Table 1: Evolution of FI in the World

\begin{tabular}{|c|c|c|c|c|c|}
\hline & $\mathbf{1 9 7 0 - 7 9}$ & $\mathbf{1 9 8 0 - 8 9}$ & $\mathbf{1 9 9 0 - 9 9}$ & $\mathbf{2 0 0 0 - 0 9}$ & $\mathbf{2 0 1 0 - 1 7}$ \\
\hline \hline Foreign investment & $1.10 \times 10^{\wedge} 10$ & $5.17 \times 10^{\wedge} 10$ & $1.96 \times 10^{\wedge} 11$ & $1.5 \times 10^{\wedge} 12$ & $1.8 \times 10^{\wedge} 12$ \\
\hline Growth rate & 17.99 & 18.95 & 19.70 & 10.84 & 6.09 \\
\hline
\end{tabular}

Source: Authors' own elaboration with data from World Bank.

approaches (cross-section, time series, and panel data), that FI boosts economic activity in the world economy as shown in Table 1. It is worth noticing that $\mathrm{FI}$ in levels has increased significantly from 1970 to 2017. From this table, it can be also seen that: 1) in 1970-1979, FI grew at an average annual rate of $17.99 \%$; 2) during the period $1980-1989$, FI grew at an average annual rate of $18.95 \%$; 3 ) in 1990-1999, FI increased at an average annual rate of $19.70 \%$; 4 ) from 2000 to 2009 the average annual rate was $10.84 \%$ and, finally; 5) from 2010 to 2017, FI increased at an annual average rate of $6.09 \%$. Thus, $\mathrm{FI}$ grew at an average annual rate of $14.70 \%$ during the whole period 1970-2017. It can be concluded, that FI in the world in recent decades has had an accelerated pace.

This paper attempts to find empirical evidence on the nexus between $\mathrm{FI}$ and EG for sixteen economies belonging to the Organization for Economic Cooperation and Development (OECD) from 1977 to 2017 with information from the World Bank. To do this, a Granger causality analysis is carried out and, subsequently, static and dynamic panel data models are estimated.

With respect to the current state of the subject, this research is distinguished in the following: 1) it is concentrated in several countries belonging to the OECD, Australia, Canada, Germany, Spain, Finland, France, United Kingdom United, Greece, Italy, Japan, Republic of Korea, Mexico, the Netherlands, Norway, New Zealand and USA; 2) there is a greater availability of data with respect to the past, 3) panel data models are estimated, which allows a greater number of countries, variables and periods to be used; and 4) problems of multicollinearity and autocorrelation are corrected.

The rest of the document is organized as follows: section 2 deals with a short review of the literature; section 3 presents the descriptive statistics of the relevant variables; section 4 deals with the specification of the panel data models; section 5 discusses the main empirical findings regarding Granger's causality and the estimation of static and dynamic panel data models; finally, derived from this research, section 6 provides conclusions and some policy recommendations.

\section{FOREIGN INVESTMENT AND ECONOMIC GROWTH}

The impact of FI on economic activity in Mexico has been analyzed in several investigations; we mention, for instance, Sepúlveda and Chumacero (1983), Dussel-Peters (2000), Márquez-Pozos et al. (2003), Garriga (2014), and Venegas-Martínez and LópezHerrera (2014). On the other hand, Mortimore et al. (2001) deal with corporate strategies for $\mathrm{FI}$ to boost economic growth in Latin America. Moreover, Li and Liu (2005) study the relationship between $\mathrm{FI}$ and economic growth by using a panel of data for 84 countries over three decades, Rashid-Mohamed et al. (2013) assess the impact of FI and domestic investment on economic growth in Malaysia, Gui-Diby (2014) attend to the effects of FI on economic growth in Africa by using a three-decade panel data model, Tang and Tan (2017) analyze the relationship between FI and economic growth in Malaysia, finally Lin and benjamin (2018) study causal relations among energy consumption, $\mathrm{FI}$ and economic growth in Mexico, Indonesia, Nigeria and Turkey. According to some of the papers mentioned above, $\mathrm{FI}$ is usually complementary to the local economic growth and development effort. It has indirect advantages that are often more important than the direct or tangible ones, for instance: 1) entry of new technology; 2) training of personnel; 3) competitiveness in the sectors in which is inserted; 4) fiscal income; and 5) financing the balance of payments (Sepúlveda and Chumacero, 1983).

$\mathrm{FI}$ is usually oriented towards the economies with the highest growth rates. Most of the $\mathrm{Fl}$ in the world moves among developed countries. That is, most of the flows are oriented to the United States, the European Union and Japan. Thus, FI is oriented towards the most dynamic sectors of the world economy. In the 1960s and the 1970s, it moved towards mining extraction. Later in the 1980s and the 1990s, it was oriented towards the manufacturing sector. From 2000 to 2008, 
it was oriented to the sector of financial services, such as banks and insurers. In summary, FI, generally, employs and demands highly qualified personnel, compared to domestic companies, and supports the financing of economic growth.

It should be noted that $\mathrm{FI}$ is a complement for economic development of the recipient country, which must be taken into account in the design of long-term strategies. The long-term growth policy must be based on the internal effort, while taking advantage of an external environment, which is very dynamic. In this regard, Borensztein et al. (1998) study the effects of FI on EG in several countries along two decades, and suggest that foreign direct investment is a relevant vehicle for technology transfer, which in turn contributes to growth of domestic investment; however, these authors point out that direct $\mathrm{FI}$ contributes to economic growth only if the recipient country has a minimum level of human capital that has the capacity to absorb advanced technologies. On the other hand, Gui-Diby (2014) states that despite the low level of human resources in the African region, $\mathrm{FI}$ has a significant impact on economic growth in a study conducted for 50 African countries in the period from 1980 to 2009.

On the other hand, Li and Liu (2005) study the interaction of $\mathrm{FI}$ with EG in 84 countries, during the period 1970-1999, through panel data models. They find that FI not only directly promotes economic growth, but also, indirectly, promotes human capital, exerting a positive effect on economic growth and reducing the technological gap in developing countries. Likewise, Rashid-Mohamed et al. (2013) analyze the impact of foreign and domestic investment in the economic growth of Malaysia, in the period 1970-2008, through a vector error correction model (VECM). These authors suggest a long-term bilateral causality between domestic investments and EG; however, they point out that there is no strong evidence of causality between $\mathrm{FI}$ and economic growth.

Moreover, Tang and Tan (2017) study the relationship between $\mathrm{FI}$ and economic development and their results indicate that the source of FI matters a lot, considering that Fl flows from North America and Southeast Asia contributes more significantly to economic growth in Malaysia, in relation to FI flows from Central and South America, Northwest Asia and Oceania. Recently, Lin and Benjamin (2018) study the causal relationship between $\mathrm{FI}$ and economic growth in Mexico, Indonesia, Nigeria, and Turkey in 1990-2014 by using a dynamic least squares model. They find that there are bidirectional causal relationships between EG and inflows of foreign direct investment.

\section{VARIABLE STATISTICS DESCRIPTION}

The Gross Domestic Product (GDP) and the FI data were obtained from World Bank; both variables are in USD at current prices. The period of study is 19772017. In this investigation a balanced panel data is available. The period is restricted to the availability of data; the panel includes sixteen OECD economies. Table 2 shows the variables that will be used, as well as their averages, standard deviations, and maximum and minimum levels for the sample of the sixteen studied economies of the OECD. The average GDP is $1.52^{\prime} 10^{\wedge} 12$, the standard deviation is $2.68^{\prime} 10^{\wedge} 12$, the smallest GDP is $1.55^{\prime} 10^{\wedge} 10$, and the largest is $1.94^{\prime}$ $10^{\wedge} 13$. The average of $\mathrm{FI}$ is $2.95^{\prime} 10^{\wedge} 10 \mathrm{USD}$, with a standard deviation of $6.86^{\prime} 10^{\wedge} 10$, a minimum of $-2.51^{\prime}$ $10^{\wedge} 10$ USD and a maximum of $7.34^{\prime} 10^{\wedge} 11$ USD.

Most of the studies on the link between FI and EG predict that there is a positive relationship between them. Below are the results of a graphical analysis, which relates the dependent variable GDP with $\mathrm{FI}$ in the economies under study. Figure 1 shows the dynamics between the logarithm $\mathrm{FI}$ and the logarithm of the GDP, for the economies analyzed in this research, supporting the idea that the expansion of $\mathrm{FI}$ is positively associated with EG.

\section{PANEL DATA ANALYSIS}

Panel data models are very useful for applied research. In our case, a panel data is a sample of characteristics that countries have over time, that is, it

Table 2: Statistics of the Variables under Study

\begin{tabular}{|c|c|c|c|c|c|}
\hline Variable & Notation & Average & Deviation & Minimum & Maximum \\
\hline \hline Gross domestic product & PIB & $1.52 \times 10^{\wedge} 12$ & $2.68 \times 10^{\wedge} 12$ & $1.55 \times 10^{\wedge} 10$ & $1.94 \times 10^{\wedge} 13$ \\
\hline Foreign investment & ied & $2.95 \times 10^{\wedge} 10$ & $6.86 \times 10^{\wedge} 10$ & $-2.51 \times 10^{\wedge} 10$ & $7.34 \times 10^{\wedge} 11$ \\
\hline
\end{tabular}

Source: Authors' own elaboration with data from World Bank. 


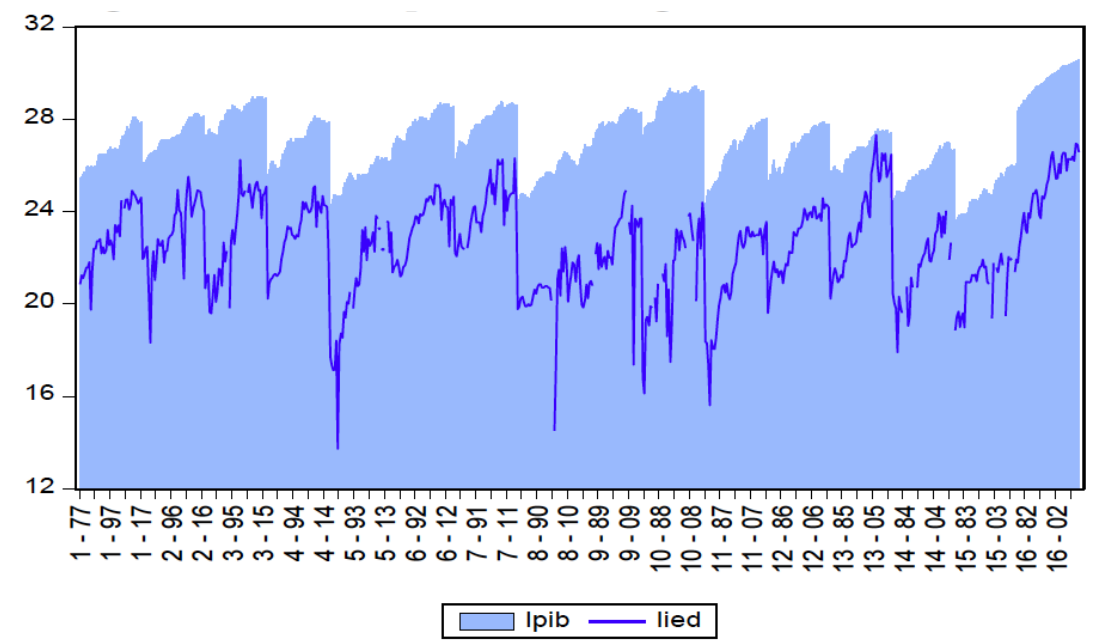

Figure 1: Relationship between foreign investment and GDP.

Source: Authors' own elaboration with data from World Bank.

is a simultaneous combination of time series and cross section data. The general model that is intended to estimate has the following form:

$y_{i t}=\alpha y_{i t-1}+\beta X_{i t}+u_{i t}$

where $y_{i t}$ is the dependent variable that changes depending on $i$ (the number of countries) and $t$ (the number of years), $y_{i t-1}$ is the lagged dependent variable, $X_{i t}$ are exogenous variables, and $u_{i t}$ stand for random disturbances. The estimates for Ordinary Least Squares (OLS) will be biased and to avoid this two models are proposed to the grouped regression: fixed effects (FE) and random effects (RE) models, which will be discussed later. The use of panel data presents several advantages because it examines a greater number of observations with more and better information, admits a greater number of variables and provides less multicollinearity between data of the explanatory variables, as well as greater efficiency in the estimation. Another advantage is that each country (observation unit) can be tracked. It also solves the problem of omitted variables, since variables that do not change in time can be eliminated by differences ${ }^{1}$.

Of course, the panel data also has disadvantages and limitations since the data is more complex: heterogeneity or individualities are not treated. If all the qualities of the country are not observable, then the errors will be correlated with the observations and the OLS estimators will be inconsistent. The fixed-effect model implies fewer assumptions about the behavior of the error term. In this case, it is assumed that the model to be estimated is given by (1). If it is also

${ }^{1}$ For a more detailed analysis of panel data see Baltagi (1995) supposed that the error term $\varepsilon_{i t}$ can be broken down into two parts, a fixed part, constant for each country $v_{i}$, and another random component $u_{i t}$ that meets the OLS requirements, that is, $\varepsilon_{i t}=v_{i}+u_{i t}$, then

$y_{i t}=\alpha y_{i t-1}+\beta X_{i t}+v_{i}+u_{i t}$

which is equivalent to making a general regression and giving each individual a point of origin (ordinates) different. The random effects model (RE) has the same specification as that of the fixed effects model with the exception that the term $v_{i}$, instead of being a fixed value for each country and constant over time it is a random variable with a mean value $E\left[v_{i}\right]$ and a variance $\operatorname{Var}\left(v_{i}\right) \neq 0$. In this way, the specification of the model is given by

$y_{i t}=\alpha y_{i t-1}+\beta X_{i t}+v_{i}+u_{i t}$

where now $v_{i}$ it is a random variable. The RE model is more efficient ${ }^{2}$ but less consistent than that of fixed effects. For the dynamic panel data estimation, the Generalized Method of Moments (GMM) is used; see, for example, Arellano and Bond (1991). The GMM estimator extended in differences developed by Arellano and Bover (1995) is based on regressions in differences to control the unobservable effects. Later, they use previous observations of the explanatory variables and lags of the dependent variables as instruments.

The GMM in differences has some disadvantages as shown by Blundell and Bond (1998), particularly when the explanatory variables are persistent over

\footnotetext{
${ }^{2}$ The variance of the estimate is smaller, that is, it is more efficient.
} 
time. The lagged levels of these variables are weak instruments for the difference equation. On the other hand, this approach biases the parameters if the lagged variable (in this case the instrument) is very close to being persistent. These authors introduce new moments on the correlation of the lagged variable and the error term. For this, the condition of covariance between the lagged dependent variable, the difference of the errors is added, the change in the lagged dependent variable, and the error level must be zero. The system GMM estimator uses a set of equations in differences that are instrumented with the lags of the equations in levels. This estimator also relates a set of equations in instrumentalized levels with the lags of the equations in differences (Bond, 2002).

In the system GMM estimator, sufficient orthogonality conditions are imposed to ensure consistent estimators of the parameters even with endogeneity problems and when individual-country effects are not observed. This approach was developed by Arellano and Bover (1995) and, subsequently, several improvements were made by Blundell and Bond (1998). The estimator thus obtained has advantages over other estimators such as FE and others, since it does not bias the parameters in small samples or in the presence of endogeneity. The optimal GMM estimator has the following form:

$\hat{\theta}_{G M M}=\left(\begin{array}{c}\hat{\alpha}_{G M M} \\ \hat{\beta}_{G M M}\end{array}\right)=\left[\left(y_{-1}^{*} ; x^{*}\right)^{\prime} z^{*} V_{N}^{-1} z^{* \prime}\left(\begin{array}{c}y_{-1}^{*} \\ x^{*}\end{array}\right)\right]^{-1}\left[\left(y_{-1}^{*} ; x^{*}\right)^{\prime} z^{*} V_{N}^{-1} z^{* \prime} y^{*}\right]$

The above equation is a system that consists of a regression that contains together information in levels and in differences in terms of moment conditions. ${ }^{3}$

\section{ANALYSIS OF EMPIRICAL RESULTS}

This section provides the obtained results from Granger causality analysis and the static and dynamic panel data models.

\subsection{Granger Causality}

Granger's causality ${ }^{4}$ is a fundamental analysis to detect the correlation between current values of a variable and past values of another variable. The test consists in establishing the null hypothesis that there is no causality between two variables, the rejection criterion is based on detecting the statistical value of $F$, and its level of probability, $p$-value statistic, associated with higher or equal levels to $0.05 .^{5}$ The causality tests for the variables of this study are presented in Table 3 between the logarithm of the GDP and the logarithm of FI in Australia, Canada, Germany, Spain, Finland, France, United Kingdom, Greece, Italy, Japan, Republic of Korea, Mexico, the Netherlands, Norway, New Zealand and the United States of America. The estimations indicate that in general, causality exists in both directions between the logarithm of the GDP and the logarithm of the volume of FI derived from 1977 to 2017 until the lag 31, from the first lag FI does cause GDP until the ninth lag; however, the GDP from the first lag to the ninth lag does not cause foreign investment. Also, from the first lag to the ninth lag the causality is unidirectional, in this period the FI causes GDP and the GDP does not cause foreign investment.

For the remaining of the period under analysis, there are 15 years where the causality is bidirectional. On the other hand, 7 years are detected where the causality is from the GDP to $\mathrm{FI}$ and the delays are: 16, $19,20,21,26-28$. From lag 32 there is no causality in any direction among the variables object of this study. In summary, Granger's causality analysis reveals that there is a unidirectional causality in the first 9 years from $\mathrm{FI}$ to GDP, and then during the following 15 years there is empirical evidence of a bidirectional causal relationship. Finally, during the whole period of study, 7 years have a unidirectional causality from EG toward FI.

\subsection{Panel Data Modeling}

The objective of this section is to develop a panel data model that allows analyzing the impact of $\mathrm{FI}$ on the growth of the GDP, focusing on a sample of sixteen economies of OECD. The variables of analysis are expressed in logarithms: Ipib is the logarithm of the GDP per capita, and lied is the logarithm of the $\mathrm{FI}$ in USD. The period analyzed is 1977-2017, which allows having 16 groups and 41 years. With the Stata package, a balanced panel is estimated. The main results are expressed in the following tables. Table 4 shows the results of four panel data estimates. The first column indicates that the dependent variable is the

${ }^{5}$ See, for instance, Gujarati and Porter (2009), Wooldrige (2011), and Greene (2012). 
Table 3: Granger Causality between FI and GDP

\begin{tabular}{|c|c|c|c|c|c|c|c|}
\hline \multicolumn{8}{|c|}{ Pairwise Granger Causality Tests } \\
\hline \multicolumn{4}{|l|}{ Null Hypothesis: } & Obs. & F-Statistic & Probability & Probability \\
\hline \multicolumn{4}{|c|}{ lied does not Granger Cause Ipib } & 589 & 1.21330 & 0.2711 & 0.3893 \\
\hline \multicolumn{5}{|c|}{ Ipib does not Granger Cause lied } & 35.0564 & 0.0000 & 0.0000 \\
\hline 0.7797 & 0.2369 & 0.2956 & 0.0848 & 0.3057 & 0.1480 & 0.1252 & 0.2548 \\
\hline 0.0019 & 0.0019 & 0.0296 & 0.0008 & 0.0013 & 0.0061 & 0.0386 & 0.1554 \\
\hline Lag 11 & Lag 12 & Lag 13 & Lag 14 & Lag 15 & Lag 16 & Lag 17 & Lag 18 \\
\hline Probability & Probability & Probability & Probability & Probability & Probability & Probability & Probability \\
\hline Lag 19 & Lag 20 & Lag 21 & Lag 22 & Lag 23 & Lag 24 & Lag 25 & Lag 26 \\
\hline Probability & Probability & Probability & Probability & Probability & Probability & Probability & Probability \\
\hline 0.0271 & 0.0130 & 0.0105 & 0.1872 & 0.2184 & 0.3722 & 0.3530 & 0.0215 \\
\hline 0.7995 & 0.9333 & 0.8308 & 0.7619 & 0.7483 & 0.6764 & 0.5106 & 0.3260 \\
\hline Lag 27 & Lag 28 & Lag 29 & Lag 30 & Lag 31 & Lag 32 & & \\
\hline Probability & Probability & Probability & Probability & Probability & Probability & & \\
\hline 0.0193 & 0.1026 & 0.2801 & 0.2220 & 0.2696 & NA & & \\
\hline 0.5065 & 0.7223 & 0.6926 & 0.7726 & 0.9102 & NA & & \\
\hline
\end{tabular}

Ipib: log gross domestic product, lied: log foreign investment.

Table 4: Estimates of Static Panel Data

\begin{tabular}{|c|c|c|c|c|}
\hline Dependent variable: Ipib & OLS & BE & RE & FE \\
\hline \hline lied & $\begin{array}{c}0.356643 \\
(0.000)\end{array}$ & $\begin{array}{c}0.6768039 \\
(0.003)\end{array}$ & $\begin{array}{c}0.356643 \\
(0.000)\end{array}$ & $\begin{array}{c}0.35559 \\
(0.000)\end{array}$ \\
\hline Constant & $\begin{array}{c}19.05459 \\
(0.000)\end{array}$ & $\begin{array}{c}11.85092 \\
(0.016) \\
(0.05459\end{array}$ & $0.000)$ & 0.6331 \\
\hline$R^{2}$ & 0.4713 & 0.4729 & 0.6331 & Prob $>$ Chi2=0.0000 \\
\hline ML BP & & & 16 & Prob $>$ Chi2=0.0000 \\
\hline Hausman & & & 16 & 16 \\
\hline Number of countries & 628 & 628 & 628 & 628 \\
\hline
\end{tabular}

Standard error in parentheses. Source: Authors' own elaboration with data from World Bank, Stata 11. GDP: Gross Domestic Product.

logarithm of the real GDP per capita, the explanatory variable is the logarithm of the FI. The coefficient of determination is estimated for the models and the Lagrange and Hausman Multiplier tests are carried out.

The second column of Table $\mathbf{4}$ shows the estimate by OLS that gives a positive and significant coefficient of the logarithm of $\mathrm{FI}$ (lied). It also indicates adequate and significant sign for the constant. Finally, it is important to highlight that, in this case, $R^{2}$ is 0.4713 . The third column presents the results of the crosssection estimation where a positive and significant sign is observed for the logarithm of Fl. Here, the determination coefficient $R^{2}$ is 0.4729 . The fourth column shows the estimate by $R E$, this indicates positive and significant coefficients for the logarithm of 
Table 5: Estimates of Dynamic Panel Data with GMM

\begin{tabular}{|c|c|c|c|c|}
\hline $\begin{array}{l}\text { Dependent variable: } \\
\text { Ipib }\end{array}$ & $\begin{array}{l}\text { Difference GMM } \\
\text { (one stage) }\end{array}$ & $\begin{array}{l}\text { Difference GMM } \\
\text { (two stages) }\end{array}$ & $\begin{array}{c}\text { System GMM } \\
\text { (one stage) }\end{array}$ & $\begin{array}{l}\text { System GMM } \\
\text { (two stages) }\end{array}$ \\
\hline IpibL1 & $\begin{array}{c}0.905312 \\
(0.000)\end{array}$ & $\begin{array}{c}0.9028238 \\
(0.000)\end{array}$ & $\begin{array}{c}1.006857 \\
(0.000)\end{array}$ & $\begin{array}{c}0.9919748 \\
(0.000)\end{array}$ \\
\hline lied & $\begin{array}{c}0.0249639 \\
(0.000)\end{array}$ & $\begin{array}{c}0.026648 \\
(0.000)\end{array}$ & $\begin{array}{c}-0.0057279 \\
(0.237)\end{array}$ & $\begin{array}{c}0.0120103 \\
(0.378)\end{array}$ \\
\hline Constant & $\begin{array}{c}2.056894 \\
(0.000)\end{array}$ & $\begin{array}{c}2.090618 \\
(0.000)\end{array}$ & & \\
\hline $\mathrm{AR}(1)$ & & Prob $>Z=0.0005$ & Prob $>Z=0.000$ & Prob $>Z=0.001$ \\
\hline $\mathrm{AR}(2)$ & & Prob $>Z=0.0291$ & Prob $>Z=0.000$ & Prob $>Z=0.026$ \\
\hline Sargan Test & Prob $>$ Chi2 $=0.000$ & Prob $>$ Chi2 $=1.000$ & Prob $>$ Chi $2=0.000$ & Prob $>$ Chi $2=0.000$ \\
\hline Number of countries & 16 & 16 & 16 & 16 \\
\hline Number of observations & 573 & 573 & 612 & 612 \\
\hline
\end{tabular}

Standard error in parentheses. Source: Authors' own elaboration with data from World Bank, Stata 11 GMM: Generalized method of moments.

$\mathrm{FI}$ and the constant, the coefficient of determination $R^{2}$ is 0.6331 . The last column shows the estimation results by $\mathrm{FE}$, indicating positive and significant signs for the logarithm of $\mathrm{FI}$ and the constant. Here, the coefficient of determination $R^{2}$ is 0.6331 . Subsequently, the Lagrange Multiplier test is presented ${ }^{6}$ it provides a prob $>$ chi2 $=0.0000$, which indicates that the estimate by $\mathrm{RE}$ is preferable to the estimate by OLS. Subsequently the Hausman test is presented $^{7}$ with prob $>$ chi2 $=0.000$ indicating that the estimate by FE is preferable to the estimate by $\mathrm{RE}$. To mitigate the autocorrelation problems, dynamic panel data models are next estimated, the main results are shown in Table 5.

Table 5 shows the results of the dynamic panel data estimates. The first column indicates that the dependent variable is the logarithm of the GDP, the lag of the logarithm of the GDP (IpibL1), the logarithm of $\mathrm{FI}$, the constant, the first-order and second-order serial autocorrelation tests, the Sargan test ${ }^{8}$, number of countries and number of observations. The second column of the Table 5 shows the results of the estimation by difference GMM in one stage, the coefficients of the lagged per capita GDP, FI and the constant, it presents appropriate and significant signs, the Sargan test does not reject the null hypothesis, therefore the general validity of the instruments and the

\footnotetext{
${ }^{6}$ If the test is not rejected, there are no differences between OLS and RE, and it is preferable to use the ordinary least squares method.

${ }^{7}$ The null test hypothesis of Hausman is that the estimators of Random Effects and of Fixed Effects do not differ substantially, if it rejects the null hypothesis, as in this case, it is convenient FE.

${ }^{8}$ It was instrumentalized with two lags at most.
}

specification of the model are admitted. The third column shows the results of the estimation by difference GMM in two stages. Here, the coefficient of lagged GDP, the coefficient of $\mathrm{FI}$ and the constant show adequate and significant signs, the first-order serial autocorrelation is not rejected $^{9}$, nor is the second-order autocorrelation rejected. The Sargan test rejects the null hypothesis of over-identification, therefore the general validity of the instruments is not admitted, nor the specification of the model. The fourth column presents the estimates by system GMM in one stage, the coefficient of the lagged GDP is positive and significant, however, the coefficient of FI presents an unexpected negative sign, but this coefficient is not significant, On the other hand, the tests show that there are problems of serial autocorrelation of first order and second order. The Sargan test does not reject the correct use of instruments. The fifth column presents the estimates by system GMM in two stages, the coefficient of the lagged GDP is positive and significant; however, the coefficient of FI presents a positive but not significant sign. On the other hand, the empirical evidence shows that there are problems of first-order and second-order serial autocorrelation. The Sargan test does not reject the validity of the instruments. The estimations indicate that the best fit model, which is chosen, is the one estimated with difference GMM in one stage, indicating that the GDP is positively related to the lagged GDP (IpibL1), and it is also positively related with FI. The estimated model in

${ }^{9}$ First order autocorrelation is expected and desirable in dynamic models, but second order autocorrelation is not. 
difference GMM in one stage indicates that an increase of $1 \%$ in $\mathrm{FI}$ will have an impact of $0.0249639 \%$ in the GDP in the 16 economies of the Organization for Economic Cooperation and Development. In summary, the empirical evidence shows that $\mathrm{FI}$ has a positive impact on the GDP and, therefore, on EG, The difference GMM estimation in one stage is preferable, and thus this is the model to be chosen to explain the impact of $\mathrm{FI}$ in EG.

\section{CONCLUSIONS}

This research showed, firstly, through the review of the literature and later through the graphic analysis that the increase in FI has a positive relationship with GDP in the sixteen economies of the OECD. Subsequently, Granger's causality analysis reveals that there is a causal relationship in 31 lags, the first 9 years of causation is unidirectional from $\mathrm{FI}$ to GDP, 15 years of bidirectional causality between $\mathrm{FI}$ and GDP, and 7 years of unidirectional causality from GDP to foreign investment, which indicates that there is a strong causal relationship between $\mathrm{FI}$ and economic growth. Thus, the empirical evidence presented in this research shows that $\mathrm{FI}$ is relevant and has important effects on $E G$ in the 16 countries, members of the OECD, analyzed in this research, namely, Australia, Canada, Germany, Spain, Finland, France, the United Kingdom, Greece, Italy, Japan, the Republic of Korea, Mexico, the Netherlands, Norway, New Zealand and the United States of America. Moreover, the panel data model estimated with difference GMM in one stage showed the positive impact of $\mathrm{FI}$ on EG. The results presented here support the hypothesis of this work: there is a positive impact of the increase in FI on EG in the countries that were the object of this study in the period 1977-2017. Derived from the present investigation, economic policy decision makers are recommended to find the appropriate instruments and incentives to encourage the attraction of FI to boost EG.

This investigation on the causal link between $\mathrm{FI}$ inflows and economic growth has important implications in OECD's country members. It is shown through a panel data analysis that for some members, FI impact economic positively economic growth, which provides better opportunities for firms in the creation of possibilities for economies of scale. If we consider GDP per capita as an approximation to measure econonomic development, we have that $\mathrm{FI}$ is a complement for welfare of the recipient country, which must be considered in the design of long-term economic policies.

\section{REFERENCES}

Aali-Bujari, Alí., Francisco Venegas-Martínez and Gilberto PérezLechuga. 2016. "Impact of Derivatives Markets on Economic Growth in Some of the Major World Economies: A Difference-GMM Panel Data Estimation (2002-2014)." AESTIMATIO, The IEB International Journal of Finance, 12, 110-127. https://doi.org/10.5605/IEB.12.6

Aitken, Brian J. and ann Harrison. 1999. "Do Domestic Firms Benefit from Direct Foreign Investment? Evidence from Venezuela." American Economic Review, 89(3), 605-618. https://doi.org/10.1257/aer.89.3.605

Al-Qaisi, Khaldoun Maddallah. 2017. "Foreign Direct Investment and its Literature Review." Journal of Reviews on Global Economics, 6, 105-112. https://doi.org/10.6000/1929-7092.2017.06.09

Arellano, Manuel and Stephen Bond. 1991. "Some Tests of Specification for Panel Data: Monte Carlo Evidence and Application to Employment Equations." The Review of Economic Studies, 58(2), 277-297. https://doi.org/10.2307/2297968

Arellano, Manuel, and Olimpia Bover. 1995. "Another Look at the Instrumental Variable Estimation of Error-Components Models." Journal of Econometrics, 68(1), 29-51. https://doi.org/10.1016/0304-4076(94)01642-D

Baltagi, Badi H. 1995. Econometric Analysis of Panel Data. New York: John Wiley \& Sons.

Bhagwati, Jagdish. 2007. "Why Multinationals Help Reduce Poverty?" World Economy, 30(2), 211-228. https://doi.org/10.1111/j.1467-9701.2007.00879.x

Blundell, Richard and Stephen R. Bond. 1998. "Initial Conditions and Moment Restrictions in Dynamic Panel Data Models." Journal of Econometrics, 87(1), 115-143. https://doi.org/10.1016/S0304-4076(98)00009-8

Bond, Sthephen R. 2002. "Dynamic Panel Data Models: A Guide to Micro Data Methods and Practice." Portuguese Economic Journal, 1(2), 141-162. https://doi.org/10.1007/s10258-002-0009-9

Borensztein, Eduardo, Jose De Gregorio and Jong-Wha Lee. 1998. "How Does Foreign Direct Investment Affect Economic Growth?" Journal of International Economics, 45, 115-135. https://doi.org/10.1016/S0022-1996(97)00033-0

Brahim, Mariem and Houssem Rachdi. 2014. "Foreign Direct Investment, Institutions and Economic Growth: Evidence from the MENA Region." Journal of Reviews on Global Economics, 3, 328-339. https://doi.org/10.6000/1929-7092.2014.03.24

Caves, Richard E. 1971. "International Corporations: The Industrial Economics of Foreign Investment." Economica, 28, 1-27 https://doi.org/10.2307/2551748

De Gregorio, Jose. 1992. "Economic Growth in Latin America." Journal of Development Economics, 39(1), 59-84. https://doi.org/10.1016/0304-3878(92)90057-G

Donges, Juergen. 1976. "A Comparative Survey of Industrialization Policies in Fifteen Semi-Industrial Countries." Review of World Economics, 112(4), 626-659. https://doi.org/10.1007/BF02705977

Dussel-Peters, Enrique. 2000. La inversión extranjera en México. Comisión Económica para América Latina y el Caribe, Serie Desarrollo Productivo, No. 80, Santiago de Chile.

Fry, Maxwell J. 1992. Foreign Direct Investment in a Macroeconomic Framework: Finance, Efficiency, Incentives. Working Paper. The World Bank, Washington, D.C.

Garriga, Ana C. 2014. Inversión extranjera directa en México: Comparación entre la inversión procedente de los Estados Unidos y del resto del mundo. Centro de Investigación y Docencia Económica A. C., Número de Publicación 266. 
Granger, Clive W. J. 1969. "Investigating Causal Relations by Econometric Models and Cross-Spectral Methods." Econometrica, 37(3), 424-438. https://doi.org/10.2307/1912791

Greenaway, David, Robert C. Hine and Chris Milner. 1995. "Vertical and Horizontal Intra-Industry Trade: A Cross Industry Analysis for the United Kingdom." The Economic Journal, 105(433), 1505-1518. https://doi.org/10.2307/2235113

Greene, William H. 2012. Econometric Analysis, Pearson Education, 7th Edition, New York

Gui-Diby, Steve L. 2014. "Impact of Foreign Direct Investments on Economic Growth in Africa: Evidence from Three Decades of Panel Data Analysis." Research in Economics, 68 (3), 248256. https://doi.org/10.1016/j.rie.2014.04.003

Gujarati, Damodar N. and Porter, Dawn C. 2009. Econometría, Mc Graw Hill, Quinta Edición, México, D. F.

Haddad, Mona and Harrison, Ann. 1993. "Are there Positive Spillovers from Direct Foreign Investment? Evidence from Panel Data for Morocco." Journal of Development Economics, 42(1), 51-74. https://doi.org/10.1016/0304-3878(93)90072-U

Hartman, David. 1985. "Tax Policy and Foreign Direct Investment." Journal of Public Economics, 26(1), 107-121. https://doi.org/10.1016/0047-2727(85)90041-6

Krugman, Paul. 1991. "Increasing Returns and Economic Geography." Journal of Political Economy, 99(3), 483-499. https://doi.org/10.1086/261763

Li. Xiaoying and Xiaming Liu. 2005. "Foreign Direct Investments and Economic Growth: An Increasingly Endogenous Relationship." World Development, 33(3), 393-407. https://doi.org/10.1016/j.worlddev.2004.11.001

Lin, Boqiang and Benjamin I. Nelson. 2018. "Causal Relationship between Energy Consumption, Foreign Direct Investment and Economic Growth for MINT: Evidence from Panel Dynamic Ordinary Least Square Models." Journal of Cleaner Production, 197(1), 708-720. https://doi.org/10.1016/j.jclepro.2018.06.152

Magnier-Watanabe, Rémy and Jean-Paul Lemaire. 2018. "Inbound Foreign Direct Investment in Japan: A typology." International Business Review, 27(2), 431-442. https://doi.org/10.1016/j.ibusrev.2017.09.010

Marquez-Pozos, José M., Alejandro Islas-Camargo and Francisco Venegas-Martínez. 2003. "Flujos Internacionales de Capital e Inversión Extranjera de Cartera: El Caso de México 19891999." El Trimestre Económico, 70(280), 791-833.
Mortimore, Michael. 2000. "Corporate Strategies for FDI in the Context of Latin America's New Economic Model." World Development, 28(9), 1611-1626. https://doi.org/10.1016/S0305-750X(00)00048-6

Mortimore, Michael, Sebastián Vergara and Jorge Katz. 2001. La competitividad internacional y el desarrollo nacional: Implicancias para la política de inversión extranjera directa (IED) en América Latina. Comisión Económica para América Latina y el Caribe, Serie Desarrollo Productivo, No. 107, Santiago de Chile.

Ozawa, Terutomo. 1996. "The new Economic Nationalism and the "Japanese Disease": The Conundrum of Managed Economic Growth." Journal of Economic Issues, 30(2), 483-491. https://doi.org/10.1080/00213624.1996.11505812

Ozturk, Ilhan. 2007. "Foreign Direct Investment-Growth Nexus: A Review of the Recent Literature." International Journal of Applied Econometrics and Quantitative Studies, 4(2), 79-98.

Rashid-Mohamed, Masoud. Keshminder Singh and Chung-Yee Liew. 2013. "Impact of Foreign Direct Investment and Domestic Investment on Economic Growth of Malaysia." Malaysian Journal of Economic Studies, 50(1), 21-35.

Romer, Paul. 1993. "Idea Gaps and Object Gaps in Economic Development." Journal of Monetary Economic Studies, 32(3), 543-573. https://doi.org/10.1016/0304-3932(93)90029-F

Sepúlveda, Bernardo, and Antonio Chumacero. 1983. La inversión extranjera en México. Fondo de Cultura Económica, Segunda reimpresión. México.

Tang, Chor F. and Eu C. Tan. 2017. "Does the Source of Foreign Direct Investment Matter to Economic Growth in Malaysia?" Global Economic Review, 47(2), 174-181. https://doi.org/10.1080/1226508X.2017.1406815

Venegas-Martínez, Francisco and Francisco López-Herrera. 2014. Dynamics of Foreign Portfolio Investment in Mexico: Policy Recommendations. Munich Personal RePEc Archive, MPRA Paper No. 57545.

Vernon, Raymond. 1966. "International Investment and International Trade in the Product Cycle." Quarterly Journal of Economics, 80, 190-207. https://doi.org/10.2307/1880689

Wooldridge, Jeffrey M. 2011. Introducción a la econometría. Un enfoque moderno. Cengage Learning. Cuarta Edición. México.

Zhang, Qink and Bruce Felmingham. 2001. "The Relationship between Inward Direct Foreign Investment and China's Provincial Export Trade." China Economic Review, 12(1), 8299 https://doi.org/10.1016/S1043-951X(01)00044-X

\section{DOI: https://doi.org/10.6000/1929-7092.2019.08.72}

(C) 2019 Aali-Bujari et al.; Licensee Lifescience Global.

This is an open access article licensed under the terms of the Creative Commons Attribution Non-Commercial License (http://creativecommons.org/licenses/by-nc/3.0/) which permits unrestricted, non-commercial use, distribution and reproduction in any medium, provided the work is properly cited. 